\title{
FACTORS INFLUENCING NON-PERFORMING LOANS: EMPIRICAL EVIDENCE FROM COMMERCIAL BANKS IN MALAYSIA
}

\section{DOI: 10.17261/Pressacademia.2021.1448 \\ RJBM- V.8-ISS.3-2021(1)-p.160-166}

\author{
Mugahed Mahyoub¹, Rasidah Mohd Said² \\ ${ }^{1}$ Universiti Kebangsaan Malaysia, Graduate School of Business, Bangi, Selangor Malaysia. \\ mugahed.mahyoub2022@gmail.com ,ORCID: 0000-0002-3806-6123 \\ ${ }^{2}$ Universiti Kebangsaan Malaysia, Graduate School of Business, Bangi, Selangor Malaysia. \\ rasidah@ukm.edu.my, ORCID: 0000-0001-7427-1004
}

\begin{tabular}{l}
\hline Date Received: April 23, $2021 \quad$ Date Accepted: July 20, 2021 \\
\hline To cite this document \\
Mahyoub, M., Mohd Said, R. (2021). Factors influencing non-performing loans: empirical evidence from commercial banks in Malaysia.Research \\
Journal of Business and Management (RJBM), Vol.8(3), 160-166. \\
Permanent link to this document: $\underline{\text { http://doi.org/10.17261/Pressacademia.2021.1148 }}$ \\
Copyright: Published by PressAcademia and limited licensed re-use rights only.
\end{tabular}

\section{ABSTRACT}

Purpose- The purpose of this research is to examine the factors influencing non-performing loans (NPLs) ratio for Malaysian commercial banks from the period 2010 to 2018.

Methodology- Bank-specific factors and macroeconomic factors were included in the analysis. Using panel data of fifteen commercial banks in Malaysia.

Findings- The finding reveals that capital adequacy ratio is a significant factor in influencing the sample banks' level of non-performing loans. All other bank-specific factors employed in the analysis were found to be insignificant. In addition, based on the results provided by real gross domestic products and inflation, we can conclude that economic situation does not impact the non-performing loans level of the sample commercial banks.

Conclusion- It has been concluded that the loan quality of the sample bank is questionable. In order to ensure an effective operating and high performance of banks, banks require a deep concentration on their loan quality that would not only generate income, but also minimize negative and ineffective outcome to the banks. In addition, this study can be valuable to supervisory authorities, governments, and the banking industries in forecasting non-performing loans as this study shows the determinants that shape the level of Non-performing loans.

Keywords: Bank-specific factors, macroeconomic, panel data analysis, non-performing loans, Malaysian Commercial Banks. JEL Codes: G21, G20, G29

\section{INTRODUCTION}

Banking system plays an important role in mobilizing funds and is the backbone of economic activities in Malaysia. In 2017, credit extended by the banking system was $116.37 \%$ of the country's GDP, an increase of more than $23 \%$ since 2007 . Banking system also is an important entity of monetary policy, where savings are channeled into investment, thereby supporting economic growth of the country. Hence, a strong banking system is vital for the country. The improvement made in the banking system post 1997 crisis have strengthened the banking institutions in Malaysia and the Asian region. Foundations put in place after this crisis has strengthened the resilience of banking institutions during the $2007 / 2008$ global financial crisis.

Malaysian banking institutions can be categorized into three categories: commercial banks, investment banks and Islamic banks. As of 2020, there are a total of twenty-six (26) commercial banks operating in Malaysia, of which eight are domestic commercial banks and eighteen are foreign commercial banks (Bank Negara Malaysia, 2020). The smaller number of domestic commercial banks compared to foreign commercial banks are as a result of the initiatives following 1997/1998 Asian financial crisis.

The breakdown of US subprime mortgage market in 2007 influenced the country's banking system as well as the global financial system. The collapse of main banking institutions during this event has proven the significance of liquidity in banking institutions. 
This resulted in the revamp of banking regulation through the introduction of Basel III. Basel III is aimed to enhance the ability of the banking sectors to face the financial or economic crisis. Thus, Basel III introduces two entirely new liquidity requirements besides the capital requirements changes.

Like the level of liquidity, non-performing loans (NPLs) is also another key indicator in bank management. The non-performing loans' size also plays a vital role in the banking sector stability of a country. International Monetary Fund (2019) defined NPLs as those loans in which the payments of interest or principals are not served for 90 days or more; or capitalization of interest payments is equal to 90 days or more, which means it has been reinvested into principal amounts. NPLs in Malaysia stood at RM27.1 billion in December 2019. Although the size has been stabilized for a number of years, the variation in the level of NPL across the years and banks is a matter of concern of the regulator.

The mortgage crisis of 2008/2009 has also witnessed the reviving interest of researchers on banking crisis and its devastating influence on the entire economy (Mpofu and Nikolaidou, 2018). Non-performing loans were extremely significant following the crisis and this further has caused banks to fail which eventually affecting the economy. NPLs reflects credit risk and has an influence on performance of banks, which may also cause financial and economic distress (Jabbouri and Naili, 2019).

Although banks face multiple risks in their operation, credit risk is no doubt one of the key risks in commercial banks due to their nature of business. Higher credit risk influences banks' loan portfolio quality. NPLs ratio assists banks in identifying the quality in a loan portfolio. Worsening of NPLs levels influences not only the banks' liquidity and profitability, but it might also imperil the banking stability (Koštálová, 2018). Therefore, examining the factors of NPLs is significant for regulatory authorities and banks.

The next section of this paper is arranged as follows. The issue of non-performing loans and discussion of the existing empirical evidence is being reviewed in Section 2. The following section summarizes the data and methodology used to test the hypothesis related to non-performing loans. Then, the analysis of the results and discussion in Section 4, and lastly Section 5 concludes.

\section{LITERATURE REVIEW}

Numerous studies on NPLs have exclusively concentrated on two sources of determinants that are responsible for the changes in NPLs of banking institutions: bank-specific factors and country-specific (macroeconomic) factors. Keeton and Morris (1987) proposed that not only local economic conditions influence the loss rates of banking institutions, but bank-specific factors such as risk-taking behaviour and credit management contributes to the loss rates. Espinoza and Prasad (2010) investigated NPLs determinants for 80 banks in Gulf Cooperation Council from 1995 to 2008. They revealed that NPLs in these sample banks are determined by both macro-factors and bank-specific factors. GDP and interest rates appeared to be the dominant macro-factors, while capital size, credit growth and efficiency were found to be the significant bank-specific factors. In addition, they also found that the conditions of global financial market have an influence on the NPLs of these sample banks.

Louzis et al., (2012) investigated the factors that drive NPLs in nine biggest banks in Greece employing quarterly data 2003 Q1 to 2009Q3. Analysis were done on three categories of loans: consumer loans, business loans, and mortgage loans. They found that real growth of GDP, unemployment rate, public debt, and the lending rates do influence NPLs of banks. The effect of these determinants on NPLs depends on loans categories. Specifically, consumer loans were most sensitive for changes in lending rates, business loans to the real GDP growth, and mortgage loans were the least sensitive to changes in macroeconomic variables. With respect to bank-specific determinants, their results indicate that these determinants' effect on the NPLs varies between different categories of loans.

Similarly, Makri et al., (2014) studied the influence of macroeconomic and bank-specific factors on NPLs in 14 Eurozone countries, spanning from 2000 to 2008. They found that there is a strong correlation between NPLs and these two categories of determinants. Capital adequacy ratio, which represents risk-taking behaviour of banks, was found to be statistically negative significant on NPLs. Using a sample of 85 banks from Italy, Greece and Spain for the period 2004 to 2008, Messai and Jouini (2013) found that the growth of GDP and banks' profitability have negative influence on the NPLs, whereas, the rate of unemployment, real interest rates, and credit quality affect NPLs positively.

In a later development on the association between NPLs and real growth of GDP, Dimitrios et al. (2016) found that there is a positive link between these two variables. Data employed in their study was quarterly data for the year 1990 to 2015 of fifteen Euro-area countries. Their findings are consistent with Beck et al., (2015) who found that real growth of GDP, exchange rate, lending interest rate and share prices have significantly influence on the ratio of NPLs. In addition, Mpofu and Nikolaidou (2018) suggest that real GDP growth rate is an important macroeconomic variable that significantly influence NPLs. Their analysis indicates an inverse relationship between GDP growth rate and ratio of non-performing loans. Other macroeconomic variables 
such as inflation rate, domestic credit to private sector by banks as a percentage of GDP, global volatility, and trade openness are significantly positively related to the NPLS.

Other than the Eurozone, the study on factors that influence NPLs of banks have also been performed using data from other region. In MENA context, for example, Jabbouri and Naili (2019) tested the effect of bank-specific and macroeconomic determinants on NPLs across 98 banks from ten emerging countries in MENA, during 2003 and 2016. Their study revealed bank size, ratio of capital adequacy, bank-operating efficiency, profitability of the prior year, growth of GDP, inflation, unemployment, as well as public debt are the key determinants of NPLs in the region. However, growth of loan has an insignificant effect on the behaviour of nonperforming loans.

Likewise, Alshebmi et al., (2020) examined the relationship between the non-performing loans and selected bank and macroeconomic determinants of twelve Saudi commercial banks from 2009 to 2018. They found a negative correlation between NPLs and return on assets, growth of GDP, liquidity risk and credit risk of their sample banks. Unlike the results found by Jabbouri and Naili (2019), NPLs and capital adequacy ratio relationship is insignificant in the study performed by Alshebmi et al., (2020).

In his study on emerging economies for the year 2000 to 2013, Bayar (2019) grouped the variables he employed into three categories: macroeconomic variables, institutional quality variable and bank-specific variables. Macroeconomic variables are represented by growth of real GDP per capita, unemployment rate, inflation rate, government gross debt, net lending/borrowing, institutional variable is measured by economic freedom index, and bank-specific variables are domestic credit to private sectors to GDP, capital adequacy ratio, ROA, ROE, non-interest income to total income and cost to income ratio. Consistent with other studies, both real GDP growth and capital adequacy ratio were shown to be significant related to NPLs level. Further, institutional quality appeared to be negatively related with NPLs which supports findings by Boudriga et al. (2010).

Studies using data from countries of other regions mentioned above found similar results. For example, Kjosevski and Petkovski (2017), Us (2018) and Laryea et al., (2016), all confirmed that there is a link between macroeconomic and bank-specific variables with NPLs of their sample banks.

As for Asian region, Zhang et al., (2017) tested the impact of spatial spillover on NPLs for commercial banks in 31 Chinese provinces using data for the year 2005 to 2014. Their study revealed that the impact of spatial spillover plays an important role in shaping NPLs of banks in China. Consistent with studies using data from other regions mentioned above, the GDP growth and unemployment rate are significant factors in affecting NPLs of commercial banks in the provinces.

From the above literature, we can conclude that NPLs are driven by macroeconomic and bank-specific factors regardless of where the sample data came from. Accordingly, this paper intends to examine the factors affecting NPLs of Malaysian commercial banks. Precisely, it empirically investigates both bank-specific and macroeconomic factors that affect NPLs of Malaysian locally owned and foreign commercial banks.

\section{DATA AND METHODOLOGY}

The initial sample banks of this paper consist of all listed commercial banks in Malaysia. However, due to non-availability of data for some banks, we finally had a sample of seven domestic commercial banks, (also known as local ownership commercial banks) and eight foreign commercial banks. Annual data for these sample banks were obtained from annual reports for the years 2010 to 2018. The annual macroeconomic data were extracted from the World Bank Indicators database. Our analysis, therefore, was based on a balanced panel dataset of fifteen commercial banks over the period 2010-2018 comprising of 135 observations. The sample banks of this paper are shown in Table 1 below.

Table 1: List of Sample Commercial Banks (2010-2018)

\begin{tabular}{lll}
\hline No. & Name & Ownership \\
\hline $\mathbf{1}$ & Alliance Bank Malaysia Berhad & Local \\
\hline $\mathbf{2}$ & Affin Bank Berhad & Local \\
\hline $\mathbf{3}$ & RHB Bank Berhad & Local \\
\hline $\mathbf{4}$ & Public Bank Berhad & Local \\
\hline $\mathbf{5}$ & CIMB Bank Berhad & Local \\
\hline $\mathbf{6}$ & Hong Leong Bank Berhad & Local \\
\hline $\mathbf{7}$ & Malayan Banking Berhad & Local \\
\hline $\mathbf{8}$ & Bank of China (Malaysia) Berhad & Foreign \\
\hline
\end{tabular}




\begin{tabular}{lll}
\hline $\mathbf{9}$ & Bangkok Bank Berhad & Foreign \\
\hline $\mathbf{1 0}$ & Citibank Berhad & Foreign \\
\hline $\mathbf{1 1}$ & Standard Chartered Bank Malaysia Berhad & Foreign \\
\hline $\mathbf{1 2}$ & OCBC Bank (Malaysia) Berhad & Foreign \\
\hline $\mathbf{1 3}$ & United Overseas Bank (Malaysia) Berhad & Foreign \\
\hline $\mathbf{1 4}$ & HSBC Bank Malaysia Berhad & Foreign \\
\hline $\mathbf{1 5}$ & Deutsche Bank (Malaysia) Berhad & Foreign \\
\hline
\end{tabular}

Source: Bank Negara Malaysia website (www.bnm.gov.my)

The dependent variable of this paper is non-performing loans ratio (NPLS) which is the ratio of the amount of NPLs to total gross loans. The higher value of the ratio shows lower credit quality and vice versa. Independent variables of this paper are categorized into bank-specific factors and macroeconomic factors. The bank specific determinants consist of capital adequacy ratio (CAR), loans to deposit ratio (LTDR), and size of bank (BSIZE) which is measured by total assets. CAR is measured by the ratio of bank capital over its risk-weighted assets. As proposed by moral hazard hypothesis in Dimitrios et al. (2016), banks with low capital is associated with high NPLs. This is due to the incentives on the part of the banks' manager who 'rise the riskiness of their loan portfolio when their banks are thinly capitalized'. Hence higher CAR reflects that a bank is not taking excessive risk in its business and therefore, is expected to have high quality of loans. Size of banks is measured by total assets matters in this paper as it reflects economies of scale and banks scope. Higher total assets reflect the ability of banks in extending loans to businesses and households.

Aside from bank-related factors, NPLs is also anticipated to respond to macroeconomic variables. The economic cycle state has an impact on bank operation and this is reflected by the real gross domestic product (RGDP) per capita. As RGDP slows down, the demand for loans goes down, and credit quality deteriorates; hence, increasing the level of non-performing loans. Inflation (INF) measured by CPI growth rate, is another macroeconomic variable accounted for in this paper. The reason of selecting all these variables is due to their significant impact on NPL in diverse global market as supported by prior literature review such as Laryea et al., 2016; Dimitrios et al., 2016; Kjosevski and Petkovski, 2017; Us, 2018; Wood and Skinner, 2018; Bayar, 2019; Jabbouri \& Naili, 2019; Alshebmi et al., 2020; Yi et al., 2020.

The relationship of these variables are estimated using the following equation:

$$
\text { NPLit }=\beta 0+\beta 1 C A R i t+\beta 2 L T D R i t+\beta 3 B \text { Sizeit }+\beta 4 R G D P t+\beta 5 I N F t++\varepsilon i t
$$

Where $\beta 0$ is the constant term, $\beta 1$ to $\beta 5$ represents the parameter for the independent variables, $\varepsilon$ is the disturbance term of the model $i$ denotes an individual bank, and $t$ indicates year. NPL is the dependent variable that stands for Non-performing loans. CARit, LTDRit, and BSIZEit are the bank-specific factors for bank i on year t; RGDPt and INFt are the environment factors on year $t$.

To obtain an obvious insight of the NPL ratio for each bank individually, these values are shown in Table 1 below:

Table 2: Non-performing Loan Ratio for the Fifteen Sample Banks (2010-2018)

\begin{tabular}{cccccccccc}
\hline & $\mathbf{2 0 1 0}$ & $\mathbf{2 0 1 1}$ & $\mathbf{2 0 1 2}$ & $\mathbf{2 0 1 3}$ & $\mathbf{2 0 1 4}$ & $\mathbf{2 0 1 5}$ & $\mathbf{2 0 1 6}$ & $\mathbf{2 0 1 7}$ & $\mathbf{2 0 1 8}$ \\
\hline Domestic Banks & & & & & & & & & \\
\hline Alliance & $3.66 \%$ & $3.25 \%$ & $2.65 \%$ & $2.03 \%$ & $1.32 \%$ & $1.07 \%$ & $1.18 \%$ & $1.07 \%$ & $1.48 \%$ \\
\hline Affin & $3.57 \%$ & $2.68 \%$ & $2.16 \%$ & $1.88 \%$ & $1.78 \%$ & $1.88 \%$ & $1.90 \%$ & $2.98 \%$ & $3.75 \%$ \\
\hline RHB & $4.00 \%$ & $3.31 \%$ & $2.85 \%$ & $2.92 \%$ & $2.15 \%$ & $2.05 \%$ & $2.38 \%$ & $2.51 \%$ & $2.31 \%$ \\
\hline Public & $1.10 \%$ & $0.80 \%$ & $0.62 \%$ & $0.62 \%$ & $0.57 \%$ & $0.45 \%$ & $0.45 \%$ & $0.44 \%$ & $0.46 \%$ \\
\hline CIMB & $4.24 \%$ & $3.95 \%$ & $3.33 \%$ & $2.46 \%$ & $2.00 \%$ & $1.80 \%$ & $1.88 \%$ & $2.19 \%$ & $2.22 \%$ \\
\hline Hong Leong & $2.01 \%$ & $1.52 \%$ & $1.68 \%$ & $1.39 \%$ & $1.15 \%$ & $0.85 \%$ & $0.83 \%$ & $0.98 \%$ & $0.86 \%$ \\
\hline Maybank & $1.14 \%$ & $2.28 \%$ & $1.90 \%$ & $1.56 \%$ & $1.58 \%$ & $1.85 \%$ & $2.39 \%$ & $2.72 \%$ & $3.41 \%$ \\
\hline Foreign Banks & & & & & & & & & \\
\hline Bank of China & $0.30 \%$ & $0.01 \%$ & $0.72 \%$ & $0.44 \%$ & $0.33 \%$ & $0.91 \%$ & $2.12 \%$ & $1.64 \%$ & $1.00 \%$ \\
\hline Bangkok & $3.69 \%$ & $2.82 \%$ & $2.15 \%$ & $1.07 \%$ & $3.98 \%$ & $5.35 \%$ & $4.86 \%$ & $3.88 \%$ & $2.76 \%$ \\
\hline Citibank & $2.69 \%$ & $2.34 \%$ & $2.43 \%$ & $2.15 \%$ & $2.12 \%$ & $2.16 \%$ & $2.12 \%$ & $2.32 \%$ & $0.91 \%$ \\
\hline Standard Charted & $1.58 \%$ & $1.26 \%$ & $1.34 \%$ & $3.53 \%$ & $3.98 \%$ & $5.24 \%$ & $5.63 \%$ & $5.56 \%$ & $3.06 \%$ \\
\hline
\end{tabular}




\begin{tabular}{llllllllll}
\hline OCBC & $2.87 \%$ & $2.65 \%$ & $2.05 \%$ & $2.42 \%$ & $1.99 \%$ & $1.93 \%$ & $2.03 \%$ & $1.79 \%$ & $1.63 \%$ \\
\hline UOB & $2.46 \%$ & $1.74 \%$ & $1.77 \%$ & $1.72 \%$ & $1.57 \%$ & $1.68 \%$ & $1.57 \%$ & $1.70 \%$ & $1.72 \%$ \\
\hline HSBC & $2.06 \%$ & $1.90 \%$ & $1.89 \%$ & $1.74 \%$ & $1.49 \%$ & $1.78 \%$ & $2.03 \%$ & $1.82 \%$ & $1.71 \%$ \\
\hline Deutsche & $1.48 \%$ & $1.17 \%$ & $1.18 \%$ & $0.23 \%$ & $0.26 \%$ & $0.22 \%$ & $0.16 \%$ & $0.08 \%$ & $0.13 \%$ \\
\hline
\end{tabular}

Source: Authors' calculation based on data collected

Generally, the values indicate that the NPL ratio for the domestic banks has been decreasing from 2010 to 2018 . Public Bank has consistently maintained its NPL ratio below $1 \%$ across the years. On the other hand, CIMB and Maybank appear to have much larger NPL ratios. These three banks are the three largest domestic commercial banks in Malaysia. As for the foreign banks, only Bank of China has been able to keep its NPL ratios below than $1 \%$. Overall, there is variation on the level of NPL ratio across the sample banks as well as the sample period.

\section{FINDINGS AND DISCUSSIONS}

Table 2 summarizes the descriptive statistics of the variables employed in the analysis for the sample period of 2010 to 2018. There is a considerable variation between the levels of non-performing loans of the two categories of banks. For the domestic commercial banks, Maybank has the largest mean of NPL, i.e. RM5,216 million with minimum amount of RM1,797 million and maximum of RM8,070, whereas Alliance bank has the lowest mean of NPL at RM456 million. As for the foreign commercial banks, UOB has the largest mean of NPL at RM1,118 million and Deutsche Bank has the lowest mean of NPL at a little over RM5 million.

Table 3: Descriptive Statistics

\begin{tabular}{lllll}
\hline & Mean & Std. Deviation & Minimum & Maximum \\
\hline Non-performing Loan (NPL) & $1,270,290$ & 1523351 & 93 & 8070841 \\
\hline Capital Adequacy Ratio (CAR) & 0.1696 & 0.0375 & 0.1175 & 0.3408 \\
\hline Loan to Deposit Ratio (LTDR) & 0.8341 & 0.1852 & 0.1181 & 1.5506 \\
\hline Bank Size (BSIZE) & $1.10 \mathrm{E}+08$ & $1.18 \mathrm{E}+08$ & 2197303 & $5.10 \mathrm{E}+08$ \\
\hline Real Gross Domestic Product (RGDP) & 10272.89 & 1099.21 & 8428.11 & 12034.41 \\
\hline Inflation (INF) & 0.0229 & 0.0089 & 0.0088 & 0.0387 \\
\hline
\end{tabular}

Table 3 reports the correlation results and this table reveals that CAR is negatively correlated with NPLs ratio. Other indicators are positively correlated with NPLs ratio, with size of banks having the highest positive correlation with NPLs.

Table 4: Correlations

\begin{tabular}{lllllll}
\hline & NPL & CAR & LTDR & BSIZE & GDP & INF \\
\hline NPL & 1.000 & & & & & \\
\hline CAR & -0.1424 & 1.000 & & & & \\
\hline LTDR & 0.1589 & 0.2571 & 1.000 & & & \\
\hline BSIZE & 0.6987 & -0.5108 & 0.0763 & 1.000 & & 1.000 \\
\hline RGDP & 0.0963 & 0.3120 & 0.1967 & 0.1224 & -0.0765 & 1.000 \\
\hline INF & 0.0118 & 0.0326 & -0.0109 & 0.0124 & \\
\hline
\end{tabular}

We first ran the data by employing the pooled OLS and results of the analysis is presented in column 1 of Table 4 . The results show that LTDR is positively significant at $1 \%$ while RGDP is negatively significant at $5 \%$. The Breusch-Pagan LM test performed on the data, however, reveals that the Random Effect Model (REM) is more appropriate, and the analysis performed using REM shows that RGDP remains negatively significant while LTDR was found insignificant. CAR was found positively significant in this model. A further test was carried out, and the Hausman test indicates that the final model suitable for the analysis is the Fixed Effect Model (FEM). CAR and RGDP remain significant for this model. VIF for the sample data was 1.37, hence, the issue of multicollinearity has been ruled out.

Performing further diagnostic tests indicated that the variances were not constant, as reflected by its $\chi^{2}$-stat value of 12197.62 (significant at $1 \%$ level of significance), or in other words there was heteroscedasticity issues with the data. Serial correlation issues also present on the data, with an F-stat value of 53.39 (significant at $1 \%$ level of significance). These issues were rectified and final results are as shown in Column 4 of Table 4 . The final results presented in Column 4 show that CAR is the only relevant 
determinant of the NPL for the commercial banks. CAR appears to have positive relationship with NPL ratio and is significant at $1 \%$ level of significance. This means as CAR gets higher, NPL ratio gets higher as well. Higher CAR reflects that banks are well capitalized. The results of this analysis suggest that well capitalized banks do not seem particular on the quality of their assets resulting in higher level of NPLs ratio as CAR goes up. The thought that having sufficient capital will help in overcoming any loss may have led to this behaviour of banks.

Although, bank size and loan to deposit ratio were shown to be negatively related with NPLs of the sample banks that is consistent with the findings of Hu et al. (2004); Ćurak et al. (2013) and Lai et al. (2016), the relationship, however, was not significant. Lastly, our findings do not support evidence that macroeconomic factors influence NPLs as found by Messai and Jouini (2003), Bayar (2019), Kjosevski et al. (2019), Alshebmi et al. (2020) and many more.

Table 5: Panel Data Estimation Results (Dependent Variable: Non-performing Loan Ratios (NPL))

\begin{tabular}{|c|c|c|c|c|}
\hline & (1) & (2) & (3) & (4) \\
\hline & Pooled OLS & Random Effect & Fixed Effect & Rectified Model \\
\hline Constant & $0.2364 * * *$ & $0.2767^{* * *}$ & $0.2864 * * *$ & $0.2864^{*}$ \\
\hline CAR & 0.0018 & $0.1065 * * *$ & $0.1249 * * *$ & $0.1249 * * *$ \\
\hline LTDR & $0.0213^{* * *}$ & 0.0037 & -0.0069 & -0.0069 \\
\hline BSIZE & -0.0003 & 0.0009 & -0.0040 & -0.0040 \\
\hline RGDP & $-0.0244^{* *}$ & $-0.0316 * * *$ & $-0.0224^{* *}$ & -0.0224 \\
\hline INF & -0.0651 & -0.0911 & -0.0806 & -0.0806 \\
\hline Breusch-Pagan LM test & $\begin{array}{l}99.15 \\
(0.0000)^{* * *}\end{array}$ & & - & - \\
\hline Hausman test & & $\begin{array}{l}35.56 \\
(0.0000) * * *\end{array}$ & & \\
\hline Observations & 135 & 135 & 135 & 135 \\
\hline Multicollinearity (VIF) & & & 1.37 & - \\
\hline $\begin{array}{l}\text { Heteroscedasticity ( } \chi^{2}- \\
\text { stat) }\end{array}$ & & & $\begin{array}{l}12197.62 \\
(0.0000)^{* * *}\end{array}$ & - \\
\hline $\begin{array}{l}\text { Serial Correlation } \\
\text { (F-stat) }\end{array}$ & & & $\begin{array}{l}53.369 \\
(0.0000) * * *\end{array}$ & - \\
\hline
\end{tabular}

\section{CONCLUSION AND IMPLICATIONS}

The aim of this paper is to examine the factors influencing NPLs ratio for Malaysian commercial banks using data from 2010 to 2018. The empirical results indicate that only CAR has influence on NPLs of banks in Malaysia. The positive link between this variable with NPLs is rather alarming. This implies that the loan quality of the sample bank is questionable. This should be a concern to regulators as loan quality deterioration is considered as one of the main reasons why banks fail in advanced economies and the increasing bad loans is considered as one of the main sources of financial crisis (Us, 2018). The results also suggest that to ensure an effective operating and high performance of banks, banks require a deep concentration on their loan quality that would not only generate income, but also minimize negative and ineffective outcome to the banks. Unlike studies performed previously using data from other countries, real GDP and inflation have no significant impact on NPLs level of the sample banks. Results of this paper can be valuable to supervisory authorities, governments, and the banking industries in forecasting non-performing loans as this paper shows the determinants that shape the level of NPLs.

\section{REFERENCES}

Alshebmi, A. S., Adam, M. H. M., Mustafa, A. M., Thomran, M., \& Fathelbab, O. E. A. (2020). Assessing the Non-Performing Loans and their Effect on Banks Profitability: Empirical Evidence from the Saudi Arabia Banking Sector. International Journal of Innovation, Creativity and Change, 11(8), 69-93.

Bank Negara Malaysia. (2020). List of licensed financial institutions. Retrieved from https://www.bnm.gov.my/index.php?ch=fs\&pg=fs mfs list\&ac=118\&lang=en (Accessed: August 4, 2020).

Bayar, Y. (2019). Macroeconomic, Institutional and Bank-Specific Determinants of Non-Performing Loans in Emerging Market Economies: A Dynamic Panel Regression Analysis. Journal of Central Banking Theory and Practice, 8(3), 95-110. 
Beck, R., Jakubik, P., \& Piloiu, A. (2015). Key determinants of non-performing loans: new evidence from a global sample. Open Economies Review, 26(3), 525-550.

Boudriga, A., Taktak, N. B., \& Jellouli, S. (2010). Bank specific, business and institutional environment determinants of banks nonperforming loans: evidence from MENA countries. In Economic Research Forum, Working Paper, 54, 1-28.

Curak, M., Pepur, S., \& Poposki, K. (2013). Determinants of non-performing loans_evidence from South-eastern European banking systems. Banks and Bank Systems, 8(1), 45-53.

Dimitrios, A., Helen, L., \& Mike, T. (2016). Determinants of non-performing loans: Evidence from Euro-area countries. Finance Research Letters, 18, 116-119.

Espinoza, R. A., \& Prasad, A. (2010). Nonperforming Loans in the GCC banking system and their macroeconomic effects. IMF Working Papers, 10(224), 1-24.

Hu, J. L., Li, Y., \& Chiu, Y. H. (2004). Ownership and nonperforming loans: Evidence from Taiwan's banks. The Developing Economies, 42(3), 405420.

International Monetary Fund (2019). The IMF 2019 financial soundness indicators compilation guide. Retrieved from https://www.imf.org/en/Data/Statistics/FSI-guide (Accessed August 20, 2020).

Jabbouri, I., \& Naili, M. (2019). Determinants of Nonperforming Loans in Emerging Markets: Evidence from the MENA Region. Review of Pacific Basin Financial Markets and Policie, 22( 4), 1950026.

Keeton, W. R., \& Morris, C. S. (1987). Why do banks' loan losses differ? Economic Review, 72(5), 3-21.

Kjosevski, J., \& Petkovski, M. (2017). Non-performing loans in Baltic States: Determinants and macroeconomic effects. Baltic Journal of Economics,17(1), 25-44.

Kjosevski, J., Petkovski, M., \& Naumovska, E. (2019). Bank-specific and macroeconomic determinants of non-performing loans in the Republic of Macedonia: Comparative analysis of enterprise and household NPLs. Economic Research-Ekonomska Istrazivanja, 32(1), 1185-1203.

Koštálová, Z. (2018). Macroeconomic Determinants of Non-Performing Loans in the Slovak Banking Sector. edamBa@ eUBa, 247-255.

Lai, L. H., Hung, L. C., \& Kuo, C. J. (2016). Do Well-Financial Holding Company Organized Banks in Taiwan Take More Risk? Review of Pacific Basin Financial Markets and Policies, 19(04), 1650024.

Laryea, E., Ntow-Gyamfi, M., \& Alu, A. A. (2016). Nonperforming loans and bank profitability: evidence from an emerging market. African Journal of Economic and Management Studies, 7(4), 462-481.

Louzis, D. P., Vouldis, A. T., \& Metaxas, V. L. (2012). Macroeconomic and bank-specific determinants of non-performing loans in Greece: A comparative study of mortgage, business and consumer loan portfolios. Journal of Banking and Finance, 36(4), 1012-1027.

Makri, V., Tsagkanos, A., \& Bellas, A. (2014). Determinants of non-performing loans: The case of Eurozone. Panoeconomicus, 61(2), 193-206.

Messai, A. S., \& Jouini, F. (2013). Micro and macro determinants of non-performing loans. International Journal of Economics and Financial Issues, $3(4), 852-860$.

Mpofu, T. R., \& Nikolaidou, E. (2018). Determinants of credit risk in the banking system in Sub-Saharan Africa. Review of Development Finance, $8(2), 141-153$.

Us, V. (2018). The Determinants of Nonperforming Loans Before and After the Crisis: Challenges and Policy Implications for Turkish Banks. Emerging Markets Finance and Trade, 54(7),1608-1622.

Wood, A., \& Skinner, N. (2018). Determinants of non-performing loans: evidence from commercial banks in Barbados. The Business \& Management Review, 9(3), 44-64.

Yi, W. K., Mahmud, M. A. B. M., \& Suppiah, T. A. (2020). A Study on the Determinates of Credit Risk in Malaysian Banking System for the Period 1996 to 2017. International Journal of Psychosocial Rehabilitation, 24(2).

Zhang, X., Guo, D., Xiao, Y., \& Wang, M. (2017). Do Spatial Spillover Effects of Nonperforming Loans for Commercial Banks Exist? Evidence from Chinese Provinces. Emerging Markets Finance and Trade, 53(9), 2039-2051. 